\title{
Luiz Heitor Corrêa de Azevedo, Amerindian Music and Brazilian Musical Thought: A Brief Note
}

\author{
Rafael José de Menezes Bastos
}

This almost forgotten book - defended originally as a doctoral dissertation in Musical Folklore at the then National Music School of the University of Brazil in Rio de Janeiro - is the foundation text for modern studies of the musical systems of Amerindian societies in Brazil. Although, as with any text, it paying its due to its time - through a diffuse evolutionism and ethnocentrism - , it reports on the significant literature until then produced with mastery, elegance and creativity, making advances on important issues. Originating in different fields of knowledge, this literature extends from comparative musicology - I remember that the expression "ethnomusicology" was born only in 1954 - , through history, ethnography, folklore and more. Quite differently from the hegemonic studies at the time, it treats indigenous musical systems without any trace of exoticism and at the same time a vital presence in Brazil.

The book has two notable traits - among many that the reader will soon find - that I would like to stress here, because I see them paradoxically as responsible for its having been forgotten: it defends ideas about Amerindian music and the Indians in general which are totally contrary to those present in the works of two of Azevedo's great contemporaries, Luciano Gallet and Mário de Andrade. At the same time it couples musicological analysis with its socio-cultural contextualization as a fundamental mark of its construction. It is worth noting that Andrade, along with Joanídia Sodré, Assuero Garritano, Brasílio Itiberê and Renato Almeida, was a member of the committee which examined and approved the dissertation, later confessing however that he had serious restrictions to the work (Aragão 2005: 54-55).

In my text of 2006, I argued that Brazilian musical thought which was being built in the 1930's reduces the famous fable of three races to but two. Thus, the Brazilian racial triangle - formed by "whites", "blacks" and "Indians" - , becomes a simple line, defined only by the first two vertices of the triangle. The "Indian" is here dispatched to remoteness, a kind of non-Brazil inside itself, and not really part of the country nor even situated 
within it. In that text, I looked for evidence to show that the production of this retroaction was made exactly under the aegis of Andrade's and Gallet's thoughts. The latter, in his book of 1934 (Gallet 1934), published posthumously by Andrade, establishes that Brazilian music - that is to say, Brazilian folk music - was formed on the bases of Portuguese melody and harmony, and African rhythm. The absence of the "Indian" in this genealogy was attributed to the fact that their music was very different and even incompatible with the Portuguese's and "ours", having not resisted, on the other hand, influences from contact with the "whites", especially through Jesuit pedagogy. Andrade himself consolidated this argument in 1962 and 1965.

Very differently from Gallet and Andrade, Azevedo develops an analysis which leads to an understanding of indigenous music in Brazil, not as something radically dissimilar from the Portuguese's and "ours". On the contrary he argued that it was based on the same basic principles and therefore compatible to both:

"Analyzing the most developed indigenous melodies which were transmitted to us, we find some constructive logic whose principles seem to be common to the musical sense of men of all countries and all eras" $(: 40$ of the original edition).

Azevedo addressed more systematically the contribution of indigenous musical systems in the formation of Brazilian folk music in his works produced after this dissertation, typically in his also pioneering research dedicated to mapping and analyzing folk music in Brazil (see Corrêa de Azevedo, 1952: 26-27; 1954), Chase (1962: 130, 148-149), Menezes Bastos 1974, Lamas, ed., 1985, Aragão, 2006). In 1943 he founded the Center for Folklore Research at the National Music School of the University of Brazil, whose present successor is the Ethnomusicology Lab at UFRJ (see Samuel Araújo’s Brief Note)

\section{References}

ANDRADE, Mário de. 1962. Ensaio Sobre a Música Brasileira. São Paulo: Martins.

ANDRADE, Mário de. 1965. Aspectos da Música Brasileira. São Paulo: Martins. ARAGÃo, Pedro de Moura. 2005. Luiz Heitor Corrêa de Azevedo e os Estudos de Folclore no Brasil: Uma Análise de Sua Trajetória na Escola Nacional de Música (1932-1947). Rio de Janeiro: School of Music, Federal University of Rio de 
Janeiro. Master Thesis in Music.

ARAGÃo, Pedro de Moura. 2006. "Luiz Heitor Corrêa de Azevedo e o Mapeamento Musical Brasileiro”. Paper presented to ANPPOM's 15th Congress. Accessed at www.anppom.com.br/anais/anaiscongresso.../ pedro_aragao.pdf , June 20, 2011.

CHASE, Gilbert. 1962. A Guide to the Music of Latin America.Washington, D. C.: The Pan American Union/The Library of Congress.

CORRÊA DE AZEVEDO, Luiz Heitor. 1952. Bibliografia Musical Brasileira (18201950). Rio de Janeiro: Instituto Nacional do Livro.

CORRÊA DE AZEVEDO, Luiz Heitor. 1954. "Folk Music: Brazilian", Grove's Dictionary of Music and Musicians. 5th ed. Eric Blom, ed., London: Macmillan \& Co.Ltd., vol. 3, pp. 198-201.

GALLET, Luciano. 1934. Estudos de Folclore. Rio de Janeiro: Carlos Wehrs \& Cia. LAMA, Dulce Martins, Ed. 1985. Publicação Comemorativa dos 80 Anos de Luiz Heitor Corrêa de Azevedo. São Paulo: Sociedade Brasileira de Musicologia| Funarte.

MENEZES BASTOS, Rafael José de. 1974. "Las musicas tradicionales del Brasil”, Revista Musical Chilena 125: 21-77.

MENEZES BASTOS, Rafael José de. 2006. "O Índio na Música Brasileira: Recordando Quinhentos Anos de Esquecimento”, Músicas Africanase Indígenas no Brasil, Rosângela de Tugny and Ruben de Queiroz, eds., Belo Horizonte: Editora UFMG, pp. 115-127. 